\title{
KAJIAN YURIDIS TERHADAP KEDUDUKAN DANA ASURANSI DARI SUDUT PANDANG PERJANJIAN PERKAWINAN
}

\author{
Sugiri Permana \\ Pengadilan Agama Sukabumi \\ Jl. Taman Bahagia No. 19, Benteng, Warudoyong, Sukabumi \\ E-mail: sugirivermana@yahoo.co.id
}

\begin{abstract}
The Judicial Assessment of the Insurance Fund Status in the Perspective of Marriage Covenant. Ideally, if a legal case comes from the same sources of law, the solution must also be the same although examined by different courts. This case happened on the assessment of the insurance fund. In one hand, the religious courts assessed the insurance fund as heritage while the public court considered the insurance fund as absolute rights of individuals. This article examines the legal differences using treaty law approach. To enrich this analysis, the author presents several court decisions concerning the insurance fund.
\end{abstract}

Keywords: Islamic law, civil law, insurance funds, the marriage covenant

\begin{abstract}
Abstrak: Kajian Yuridis terhadap Kedudukan Dana Asuransi dari Sudut Pandang Perjanjian Perkawinan. Idealnya, jika kasus hukum itu berasal dari sumber hukum yang sama, maka penyelesaiannya juga harus sama meskipun dilakukan di pengadilan yang berbeda. Kerisauan ini terjadi pada penilaian dana asuransi, antara peradilan agama yang menilai dana asuransi sebagai warisan dan peradilan umum yang menilai asuransi sebagai hak mutlak perseorangan. Artikel ini mengkaji perbedaan hukum tersebut dengan pendekatan hukum perjanjian. Untuk memperkaya analisis ini, penulis menyajikan beberapa putusan pengadilan mengenai kasus dana asuransi.
\end{abstract}

Kata Kunci: hukum Islam, hukum perdata, dana asuransi, perjanjian perkawinan

\section{Pendahuluan}

Pada awal perkembangan asuransi Indonesia, proteksi dijadikan sebagai tujuan asuransi untuk menutupi adanya risiko di kemudian hari. Hal ini dapat dilihat pada ketentuan Pasal 246 Kitab UndangUndang Hukum Dagang (KUHD) maupun dalam Undang-Undang Nomor 2 Tahun 1992 tentang Usaha Perasuransian. Dalam perkembangan terkini, selain asuransi bersifat protektif juga bernilai investasi untuk jangka menengah maupun jangka panjang, sehingga nasabah mempunyai daya tarik tersendiri terhadap produk asuransi seperti pada asuransi dwiguna, dwiguna bertahap atau unit link. ${ }^{1}$

Perkembangan asuransi tersebut sedikit tidaknya akan berpotensi terhadap probabilitas sengketa asuransi di dunia peradilan. Selama ini, sengketa asuransi didominasi oleh gugatan klaim asuransi yang di dalamnya seringkali mempersoalkan kedudukan dana asuransi apakah

Naskah diterima: 13 Desember 2015; Direvisi: 21 April 2016; Disetujui untuk diterbitkan: 1 Juni 2016.

${ }^{1}$ Otoritas Jasa Keuangan, "Asuransi Sarana Proteksi dan Investasi," 19. http:// sikapiuangmu. ojk. go.id/.../Asuransi.pdf. sebagai harta bersama, hak warisan atau hak individual? Pada dasarnya sengketa asuransi dapat diselesaikan pada lingkungan peradilan umum dan peradilan agama. Jenis asuransi menjadi criteria utama untuk menentukan apakah sengketa tersebut menjadi kewenangan peradilan umum atau peradilan agama. ${ }^{2}$ Apabila sengketa tersebut bersumber dari asuransi syariah, penyelesaiannya menjadi kewenangan peradilan agama, sebaliknya jika sengketa tersebut berasal dari asuransi konvensional akan menjadi kewenangan peradilan agama. ${ }^{3}$ Peradilan agama juga berwenang menyelesaikan sengketa dana asuransi, jika dana tersebut menjadi bagian dari sengketa perdata yang menjadi kewenangan peradilan agama (harta bersama dan waris).

\footnotetext{
2 Dari sudut pandang hukum Islam, asuransi terdiri dari asuransi konvensional dan asuransi Syariah. Asuransi syariah dikelola berdasarkan prinsip syariah yaitu tolong menolong, di mana sebagian dana disisihkan sebagai dana tabaru' (untuk derma) dan sebagian lagi sebagai dana tabungan/ investasi dalam bentuk perjanjian usaha, lihat Fatwa Dewan Syariah Nasional Majelis Ulama Indonesia nomor 51/ DSN-MUI/III/2006. http://www.aasi.or.id/...upload/content/ regulasi _pemerintah/...51-Mudharabah_Musytarakah_Asuransi.pdf

3 Berdasarkan Pasal 49 UU Nomor 3 Tahun 2006 tentang Perubahan Atas UU Nomor 7 Tahun 1989 yang telah dirubah terakhir dengan UU Nomor 50 Tahun 2009.
} 
Terdapat perbedaan sumber hukum untuk menilai sengketa asuransi yang terdapat di lingkungan peradilan umum dan peradilan agama. Sengketa asuransi pada lingkungan peradilan umum diselesaikan dengan hukum perdata, sedangkan pada peradilan agama dilakukan dengan hukum perdata Islam. ${ }^{4}$

Menurut hukum perdata, dana asuransi menjadi hak penuh pihak yang ditunjuk dalam polis asuransi. Ketentuan tersebut berbeda dengan hukum perdata Islam yang mempunyai tiga pendapat. Pendapat pertama, apabila dana asuransi berasal dari asuransi wajib (misalnya asuransi kecelakaan Jasa Raharja), dana (santunan) tersebut menjadi hak janda/duda. Pendapat kedua, dana asuransi menjadi harta bersama di mana sebagiannya menjadi harta waris (suami/istri) yang meninggal lebih dahulu. Pendapat ketiga, dana asuransi menjadi hak penuh pihak/ahli waris yang tercantum dalam polis asuransi.

Jika membandingkan antara asuransi konvensional dan asuransi syariah, isi akad/perjanjian menjadi kunci utama untuk membedakan antara keduanya. Secara garis besar akad akan menentukan jenis asuransi, bentuk usaha serta menentukan kedudukan antara peserta dan perusahaan asuransi. ${ }^{5}$ Adapun penentuan penikmat (beneficiary) dalam polis (perjanjian asuransi) tidak menjadi bagian dari perbedaan, karena hal ini tergantung dari peserta asuransi untuk menentukan siapa yang menjadi penikmat. Dengan demikian, idealnya tidak ada perbedaan mengenai penyelesaian sengketa kedudukan dana asuransi baik diselesaikan oleh peradilan umum ataupun peradilan agama.

Artikel ini merupakan analasia terhadap dua ketentuan hukum yang berbeda dalam menilai dana asuransi. Untuk melihat pertentangan tersebut akan dilakukan dengan pendekatan hukum perjanjian. Beberapa yurisprudensansi Mahkamah Agung RI dan kasus-kasus waris yang berhubungan dengan asuransi akan menjadi objek kajian ini. Adapun yang dimaksudkan dengan asuransi dalam kajian ini adalah asuransi yang dilakukan selama perkawinan berlangsung yang berimplikasi pada harta bersama atau harta waris.

\footnotetext{
${ }^{4}$ Dana asuransi adalah dana yang diperoleh dari klaim asuransi, terkadang disebut dengan istilah uang santunan, uang asuransi atau hak pertanggungan.

${ }^{5}$ Setidaknya ada 6 hal yang membedakan asuransi syariah dengan asuransi konvensional. Adanya Dewan Pengawas Syariah, didasarkan pada tolong menolong, investasi dana berdasarkan syariah dengan prinsip bagi hasil, dana yang terkumpul tetap menjadi milik nasabah, pembayaran klaim dari dana tabarru' serta keuntungan dibagi antara peserta dan perusahaan. Gemala Dewi, Aspek-aspek Hukum Asuransi dalam Perbankan dan Perasuransian Syraiah di Indonesia (Jakarta: Kencana, 2007), 151-152. Muhammad Syakir Sula, Asuransi Syariah (life and General) Konsep dan Sistem Operasional (Jakarta: Gema Insani, 2004), h. 296-303.
}

\section{Dana Asuransi dalam Hukum Perdata dan Perdata Islam}

Asuransi merupakan bagian dari hukum perikatan, ${ }^{6}$ di mana jenis, objek maupun penyelesaian sengketa ditentukan pada saat penanggung dan tertanggung mengikatkan diri dalam perjanjian. Sesuai dengan doktrin hukum perjanjian, pucta sun servanda perjanjian mengikat sebagai undang-undang. Dalam semua bentuk asuransi, hubungan hukum antara penanggung dan tertanggung ditentukan dalam perjanjian yang disebut dengan polis asuransi. Diantara yang disebutkan dalam polis adalah pihak penanggung, tertanggung serta penikmat beneficiary. Penikmat adalah pihak ke tiga yang ditunjuk oleh tertanggung jika terjadi evenement (evenemen) yakni suatu peristiwa yang tidak dapat dipastikan terjadi atau kalaupun sudah pasti terjadi waktunya tidak diketahui dan tidak dapat diharapkan terjadi.7 Apabila tidak terjadi evenemen selama masa kontrak, dana asuransi akan dikembalikan sesuai dengan kesepakatan. Sebaliknya apabila terjadi evenemen, penanggung akan memberikan sejumlah uang sebagai sebuah jaminan atas ketidakpastian kepada orang-orang tertentu/penikmat yang telah disebutkan dalam polis.

Dalam kajian hukum perdata, dana asuransi bukan sebagai harta bersama dan bukan harta warisan, tetapi menjadi hak orang yang disebutkan dalam polis sebagai penikmat. J. Satrio menjelaskan bahwa penilaian dana asuransi bukan sebagai harta waris dilihat dari waktu perolehannya. Oleh karena dana asuransi diperoleh setelah terjadi kematian, maka dana tersebut bukan sebagai harta waris. ${ }^{8}$

Kedudukan dana asuransi tersebut telah ditegaskan dalam putusan Mahkamah Agung Nomor: $2831 \mathrm{~K} /$ Pdt/1996 tanggal 7 Juli 1999. Yurisprudensi tersebut mengandung dua kaidah hukum. Pertama, pembayaran uang asuransi harus diberikan kepada tertanggung yang namanya tercantum dalam polis, sehingga sesuai dengan adagium setiap pembayaran uang asuransi harus selalu melihat polis secara transparan akan menunjuk siapa yang berhak menerima uang klaim. Kedua, pembayaran uang asuransi yang menyimpang dari ketentuan Polis merupakan perbuatan melawan hukum. ${ }^{9}$

\footnotetext{
${ }^{6}$ Berdasarkan Pasal 1774 KUHPerdata, asuransi termasuk jenis perjanjian untung-untungan aleatory contract, R. Subekti, Aneka Perjanjian (Bandung: Alumni, 1977), h. 136.

7 Polis merupakan bukti tertulis adanya perjanjian asuransi antara penanggung (perusahaan asuransi) dengan tertanggung (peserta asuransi). Lihat Pasal 255 KUHD, Abdul Kadir Muhammad, Pokokpokok Pertanggungan (Bandung: Citra Aditya Bakti, 1990), 58.

${ }^{8}$ J. Satrio, Hukum Waris (Bandung: Alumni, 1992), h. 11.

${ }_{9}$ Mahkamah Agung RI, Yurisprudensi Mahkamah Agung RI (Jakarta: MARI, 2000), h. 1.
} 
Kedudukan dana asuransi dalam hukum perdata berbeda dengan hukum perdata Islam. Dalam hukum perdata Islam dibedakan antara dana asuransi yang diperoleh dari asuransi wajib compulsory insurance dan asuransi sukarela voluntary insurance. Asuransi wajib seperti dana asuransi Jasa Raharja menjadi hak janda/ duda tertanggung. Hal ini dapat dilihat pada putusan Mahkamah Agung RI Nomor: 97 K/AG/1994 tanggal 28 April 1995 yang menyelesaikan sengketa asuransi akibat sebuah kecelakaan. Putusan ini mengoreksi putusan tingkat banding (PTA Banda Aceh) dan tingkat pertama (PA Banda Aceh).

Putusan Pengadilan Agama Banda Aceh Nomor: 12/Pdt.G/1992/ PA.BNA tanggal 27 Desember 1993 menjelaskan bahwa dana kecelakaan adalah harta tirkah dengan landasan definisi tirkah yang dikemukakan oleh beberapa ulama bahwa tirkah adalah harta yang ditinggalkan atau hak-hak kebendaan lain. Putusan tersebut juga mengemukakan penafsiran ekstentsif terhadap pasal 12 (1) Peraturan Pemerintah Nomor 17 Tahun $1965,{ }^{10}$ bahwa urutan pertama yaitu janda atau duda dalam peraturan tersebut harus ditafsirkan sebagai tertunjuk untuk menerima uang asuransi bukan untuk memiliki seluruhnya. Pertimbangan hukum tersebut dikuatkan oleh Putusan Pengadilan Tinggi Agama Banda Aceh Nomor: 35/Pdt.G/1993/PTA.BNA tanggal 27 Desember 1993 dengan menambah pertimbangan hukum lain. Menurut PTA Banda Aceh, dana asuransi kecelakaan dipersamakan dengan diyat sebagaimana yang terjadi pada masa Umar ra. Pada awalnya Umar tidak memberikan hak waris diyat kepada istri terbunuh, tetapi dengan adanya informasi dari Dhahhak bin Sufyan al-Kilabi bahwa Rasulullah memberikan hak waris kepada istri Asyyam al-Dhababiy dari diyat suaminya, kemudian Umar memberikan hak waris untuk istri terbunuh dan ahli waris lainnya. ${ }^{11}$ Mahkamah Agung menilai putusan PA Banda Aceh dan PTA Banda Aceh tidak mencerminkan rasa keadilan dan tidak bijaksana dalam menerapkan hukum, karena seharusnya kedua Pengadilan tersebut memberlakukan hukum yang khusus dalam perkara tersebut yaitu Pasal 12 Peraturan Pemerintah Nomor 17 Tahun 1965. Dana kecelakaan tersebut tidak dapat dikatagorikan sebagai harta peninggalan melainkan hak dari janda yang ditinggal mati oleh suami yang mengalami kecelakaan. ${ }^{12}$ Dengan

\footnotetext{
${ }^{10}$ Pasal tersebut berbunyi, “yang berhak mendapat ganti kerugiaan pertanggungan dalam hal kematian korban adalah jandanya/dudanya yang sah".

${ }^{11}$ Hadis Nomor 1415, Imam al-Tirmidzi, al-Jami' al-Kabir (Berut: Dar al-Gar al-Islam,1996), h. 83.

12 Ikatan Hakim Indonesia, Varia Peradilan, Majalah Hukum Tahun XIV No. 159 Desember 1998, h. 22-35.
}

memperhatikan yurisprudensi di atas, terdapat kesamaan antara hukum perdata dengan hukum perdata Islam dalam menilai dana asuransi wajib bukan sebagai harta warisan tetapi hak penuh bagi janda/duda.

Perbedaan hukum perdata dan hukum perdata Islam terjadi dalam menilai dana asuransi yang diperoleh sebagai akibat evenemen (bukan dari asuransi wajib). Dalam hukum perdata Islam, "belum ada kata sepakat" mengenai kedudukan dana asuransi tersebut apakah sebagai harta bersama/yang dapat diwariskan ataukah menjadi hak sepenuhnya bagi penikmat yang ditunjuk dalam polis.

Setidaknya ada dua putusan waris yang berbeda berkenaan dengan dana asuransi tersebut. Pertama, putusan Mahkamah Agung RI Nomor 16 K/AG/2010 tanggal 30 April 2010. Putusan ini menetapkan setengah dari nilai asuransi Rp. 50.000.000,- (lima puluh juta rupiah) adalah harta waris yang harus dibagikan. Dalam putusan ini tidak ada pertimbangan yang spesifik berkenaan dengan dana asuransi, sehingga pertimbangan hukumnya dapat dilihat pada putusan tingkat pertama dan tingkat banding. Dalam putusan Pengadilan Tinggi Agama Makasar Nomor: 59/Pdt.G/2009/PTA.Mks tanggal 15 Juli 2009 dan putusan Pengadilan Agama Makasar Nomor 732/ Pdt.G/2008/ PA.Mks tanggal 2 Maret 2009 menilai dana asuransi merupakan harta bersama antara pewaris dengan istrinya karena disamping asuransi tersebut atas nama pewaris juga premi yang telah dibayarkan kepada pihak Asuransi bersumber dari harta bersama. Majelis Hakim juga mempertimbangkan mengenai polis asuransi, bahwa penunjukan istri sebagai penerima uang asuransi sifatnya admistratif karena ahli waris sesungguhnya bukan hanya istri pewaris.

Kedua, putusan Pengadilan Tinggi Agama Bandung Nomor: 168/Pdt.G/2012/PTA.Bdg tanggal 19 Juli 2012 yang mengoreksi putusan Pengadilan Agama Bekasi Nomor: 1526/Pdt.G/2010/PA.Bks tanggal 21 Desember 2011, sepanjang pertimbangan tentang dana asuransi, putusan tersebut telah dikuatkan oleh putusan Mahkamah Agung RI Nomor: 197K/AG/2015 tanggal 11 Maret 2015. Putusan PTA Bandung tersebut menyertakan yurisprudensi Mahkamah Agung Nomor: $2831 \mathrm{~K} / \mathrm{Pdt} / 1996$ tanggal 7 Juli 1999 dengan menegaskan bahwa dalam hukum asuransi jika terjadi evenemen (peristiwa yang tidak pasti/kematian) yang berhak menerima pembayaran uang pertanggungan adalah penikmat, biasanya berupa orang, badan, atau ahli waris yang ditunjuk dalam polis. Selain pertimbangan tersebut, asuransi tidak tunduk pada hukum perkawinan dan hukum kewarisan, oleh karenanya 
dana asuransi bukan harta bersama dan bukan harta warisan. ${ }^{13}$

Dari dua putusan di atas menunjukkan adanya perbedaan dalam menilai dana asuransi sebagai harta bersama atau sebagai hak kepemilikan tersendiri oleh penikmat/beneficiary yang tercantum dalam polis. Putusan pertama lebih melihat realitas pembayaran premi asuransi yang berasal dari harta bersama, sehingga dana asuransi tersebut harus dijadikan sebagai harta bersama. Sebaliknya putusan yang kedua lebih bersifat legal formal, bahwa yang berhak atas dana asuransi adalah pihak yang dicantumkan dalam polis. Putusan yang kedua sama dengan adagium asuransi yang sudah menjadi yurisprudensi tetap dan berlaku pada hukum perdata. Dengan melihat pertentangan hukum tersebut, perlu dilakukan analisa ulang terhadap kedudukan dana asuransi dengan pendekatan hukum perjanjian perkawinan.

\section{Asuransi dalam Tinjauan Perjanjian Perkawinan}

Asuransi yang dilakukan oleh seseorang dalam masa perkawinan erat kaitannya dengan ketentuan harta benda perkawinan. ${ }^{14}$ Berdasarkan hukum perkawinan di Indonesia (Undang-Undang Nomor 1 Tahun 1974/ UUP), setelah terjadinya perkawinan secara hukum pasangan suami istri mengikatkan diri terhadap lembaga harta bersama. Harta yang diperoleh selama perkawinan disebut sebagai harta bersama sedangkan harta yang diperoleh masing-masing sebelum perkawinan dan yang diperoleh sebagai hadiah atau warisan, tidak termasuk sebagai harta bersama. Bagi golongan muslim, pengaturan harta bersama lebih lanjut ditentukan pada Pasal 97 Kompilasi Hukum Islam (KHI), bahwa "janda atau dua cerai masing-masing mendapat seperdua dari harta bersama sepanjang tidak ditentukan lain dalam perjanjian perkawinan".

Hukum perkawinan (UUP dan KHI) telah merubah ketentuan harta bersama dalam KUHPerdata yang menganut asas persatuan harta kekayaan algehele gemeenschap van goederen. ${ }^{15} \mathrm{Di}$ sisi lain, KUHPerdata dan hukum perkawinan memberikan kemungkinan kepada pasangan suami istri untuk menyimpangi

${ }^{13}$ Putusan PTA Bandung Nomor: 168/Pdt.G/2012/PTA.Bdg dan putusan PA Bekasi Nomor: 1526/Pdt.G/2010/PA.Bks dapat diakses melalui putusan.mahkamakahagung.go.id.

${ }^{14}$ Dalam istilah lain disebut harta gono gini atau guna kaya, Hilman Hadikusumah, Hukum Perkawinan Indonesia Menurut Perundangan, Hukum Adat dan Hukum Agama (Bandung, Citra Aditya Bakti, 2003), h. 124.

15 Berdasarkan Pasal 119 KUHPerdata, sejak saat perkawinan terjadi persatuan harta antara suami dan istri selama tidak diperjanjikan dalam bentuk lain. ketentuan harta bersama tersebut dengan melakukan perjanjian perkawinan huwelijksvoorwaarden, baik untuk memisahkan harta perkawinan atau bentuk lainnya. ${ }^{16}$ Perjanjian perkawinan tersebut harus dibuat sebelum atau pada saat perkawinan dilakukan. ${ }^{17}$

Batasan waktu pembuatan perjanjian perkawinan tersebut sebenarnya tidak sejalan dengan asas kebebasan berkontrak pacta sun servanda yang terdapat pada Pasal 1338 KUHPerdata. Asas ini mengajarkan bahwa "semua perjanjian yang dibuat secara sah berlaku sebagai undang-undang bagi mereka yang membuatnya". Menurut Purwahid Patrik, dengan asas tersebut orang bebas membuat atau tidak membuat perjanjian, bebas menentukan isi, berlakunya dan syarat-syarat perjanjian. ${ }^{18}$ Selama perjanjian tersebut dianggap sah mempunyai ikatan hukum yang penuh. ${ }^{19}$ Atas dasar asas perjanjian tersebut sangat mungkin dibuat perjanjian perkawinan diluar waktu yang telah ditentukan selama memenuhi syarat-syarat untuk sahnya perjanjian. ${ }^{20}$

Hasil penelitian Muhammad Hikmah Tahajudin telah menemukan adanya perjanjian perkawinan yang dibuat bukan sebelum atau pada saat dilakukan perkawinan tetapi pada waktu lain dalam masa perkawinan. Perjanjian perkawinan tersebut mempunyai nilai hukum setelah disahkan oleh Pengadilan. Hal ini dapat dilihat pada penetapan Pengadilan Negeri Jakarta Barat Nomor: 326/Pdt.G.2000/PN Jkt Bar (Ang An Liong dengan Eddy Wartono), penetapan Pengadilan Negeri Jakarta Selatan Nomor: 239/Pdt.P/1998/ PN.Jkt.Sel (Anton Radjito dengan Winna Widjaya), penetapan Pengadilan Negeri Jakarta Timur Nomor: 207/Pdt.P/2005/PN.Jkt.Tim (Syam Lal Uttam dengan Kavita Utam) dan Nomor: 459/Pdt.P/2007/PN.Jkt. Tim (Dubagunta R. dengan Selvia). ${ }^{21}$

\footnotetext{
${ }_{16}$ Pasal 119 KUHPerdata, Pasal 29 UUP dan Pasal 49 KHI. Menurut Subekti, Undang-undang hanya memberi dua contoh bentuk perjanjian perkawinan yang sering terpakai yaitu percampuran laba rugi dan percampuran penghasilan. Subekti, Pokok-pokok Hukum Perdata cet 32 (Jakarta: Intermasa, 2005), 31 dan 37

17 Batasan waktu perjanjian perkawinan tersebut ternyata tidak hanya di Indonesia tetapi juga di beberapa negara muslim, seperti di Negara Maroko pada pasal 49 Mudawwana, Negara Aljazair Pasal 37.

${ }^{18}$ Purwahid Patrik, Dasar-dasar Hukum Perikatan: perikatan yang lahir dari perjanjian dan dari undang-undang (Bandung: Mandar Maju, 1994), h. 66.

${ }_{19}$ Munir Fuady, Hukum Kontrak dari Sudut Pandang Hukum Bisnis, (Bandung: Citra Aditya Bakti, 2001), h. 30.

${ }^{20}$ Syarat sahnya perjanjian dissebutkan pada KUHPerdata Pasal 1320. Kitab Undang-Undang Hukum Perdata Burgerlijk Wetboek, diterjemahkan oleh R. Subekti dan R. Tjitrosudibio, cet. 8 (Jakarta: Pradnya Paramita, 1996), hal.339. Mariam Darus Badrulzaman, KUHPerdata Buku III Hukum Perikatan Dengan Penjelasan (Bandung: Alumni,1996), h. 97.

${ }^{21}$ Muhammad Hikmah Tahajudin, "Perjanjian Kawin Setelah
} 
Penetapan-penetapan tersebut telah menunjukkan adanya urgensi perjanjian perkawinan yang dibuat pada masa perkawinan sehingga perjanjian tersebut patut disahkan. Setidaknya terdapat dua alasan ditetapkan perjanjian tersebut. Pertama, karena terjadi kealpaan atau ketidaktahuan untuk membuat perjanjian dalam waktu yang telah ditentukan. Kedua, dari sudut pandang hukum bisnis, perjanjian tersebut berguna untuk melindungi hak suami/istri atas kekayaan harta bersama dari resiko yang timbul di kemudian hari akibat perbuatan salah satu pihak. ${ }^{22}$

Dengan melihat uraian di atas, maka dapat ditegaskan bahwa pasangan suami istri dapat melakukan perjanjian perkawinan di luar waktu yang telah ditentukan dengan syarat perjanjian tersebut disahkan oleh Pengadilan. Kaidah ini menjadi bagian untuk menilai kedudukan asuransi yang dilakukan oleh salah seorang suami/istri sebagai bagian perjanjian perkawinan. Setidaknya ada tiga hal penting yang menjadi bahan pertimbangan untuk menilai asuransi tersebut sebagai bagian dari perjanjian perkawinan. Pertama, pembayaran premi asuransi berasal dari harta bersama. Kedua, apabila tidak terjadi evenemen, dana asuransi akan menjadi hak tertanggung dalam masa perkawinan sehingga dengan sendirinya menjadi harta bersama. Ketiga, dana asuransi yang terjadi karena evenemen diperuntukan bagi penikmat beneficiary yang ditunjuk dalam polis. Hal ini akan mengubah ketentuan harta bersama pada umumnya, karena pada dasarnya premi asuransi tersebut dibayar dari harta bersama tetapi setelah terjadi evenemen, dana asuransi tidak menjadi harta bersama (yang dapat diwariskan) melainkan hak bagi penikmat (janda/duda).

Dengan melihat kenyataan hukum tersebut, maka asuransi haruslah dianggap sebagai bentuk perjanjian yang menyimpangi dari ketentuan harta bersama. Legalitas asuransi sebagai bagian dari perjanjian perkawinan dipersamakan dengan perjanjian perkawinan yang dibuat selama perkawinan berlangsung. Perbedaannya, perjanjian perkawinan tersebut disahkan berdasarkan penetapan Pengadilan, sedangkan legalitas (perjanjian) asuransi sebagai perjanjian perkawinan didasarkan pada hukum asuransi yang terdapat pada KUHD dan Undang-Undang Nomor: 2 Tahun 1992 tentang Usaha Perasuransian.

Perkawinan dan Akibat Hukumnya” Tesis Universitas Diponogoro (2008), h. 70.

${ }^{22}$ Seorang suami atau istri yang menjadi direksi perusahaan mempunyai resiko untuk bertanggung jawab terhadap hutang perusahaan, Pasal 104 ayat (2-3) Undang-Undang Nomor: 40 Tahun 2007 tentang Perseoan Terbatas.

\section{Penutup}

Uraian ini menegaskan ulang tentang dana asuransi yang diperoleh akibat evenemen menjadi hak penikmat yang tertera pada polis (sebagaimana hukum perdata). Asuransi yang dilakukan selama perkawinan berlangsung, harus dianggap sebagai bagian dari perjanjian perkawinan yang menyimpangi ketentuan harta bersama di mana salah satu isi perjanjian tersebut menegaskan bahwa dana asuransi yang diperoleh akibat dari evenemen menjadi hak penuh bagi penikmat beneficiary (bukan sebagai harta bersama ataupun harta warisan).

Kesimpulan ini berbeda dengan putusan Mahkamah Agung RI Nomor: 197K/AG/2015 tanggal 11 Maret 2015 yang mengambil pertimbangan putusan Pengadilan Tinggi Agama Bandung Nomor: 168/Pdt.G/2012/PTA. Bdg tanggal 19 Juli 2012 yang menyatakan asuransi tidak tunduk pada hukum perkawinan dan hukum kewarisan. Kesimpulan ini juga berbeda dengan pertimbangan putusan Mahkamah Agung RI Nomor 16 K/AG/2010 tanggal 30 April 2010 (menggunakan pertimbangan PTA Makasar dan PA Makasar) yang menegaskan bahwa asuransi adalah harta bersama karena premi asuransi berasal dari harta bersama, sedangkan penunjukkan (janda) sebagai penikmat sifatnya admistratif karena ahli waris sesungguhnya bukan hanya istri pewaris.[]

\section{Pustaka Acuan}

Muhammad, Abdul Kadir, Pokok-pokok Pertanggungan, Bandung: Citra Aditya Bakti, 1990.

Dewi, Gemala, Aspek-aspek Hukum Asuransi dalam Perbankan dan Perasuransian Syraiah di Indonesia, Jakarta: Kencana, 2007.

Hadikusumah, Hilman, Hukum Perkawinan Indonesia Menurut Perundangan, Hukum Adat dan Hukum Agama, Bandung, Citra Aditya Bakti, 2003.

Ikatan Hakim Indonesia, Varia Peradilan, Majalah Hukum Tahun XIV No. 159 Desember 1998.

Imam al-Tirmidzi, al-Jâmi' al-Kabîr, Bayrût: Dâr alGhar al-Islam, 1996.

J. Satrio, Hukum Waris, Bandung: Alumni, 1992.

Kitab Undang-Undang Hukum Perdata Burgerlijk Wetboek, diterjemahkan R. Subekti dan R. Tjitrosudibio, cet. 8, Jakarta: Pradnya Paramita, 1996.

Mahkamah Agung RI, Yurisprudensi Mahkamah Agung RI, Jakarta, MARI, 2000.

Badrulzaman, Mariam Darus, KUHPerdata Buku III Hukum Perikatan Dengan Penjelasan, Bandung: Alumni,1996.

Tahajudin, Muhammad Hikmah, "Perjanjian Kawin Setelah Perkawinan dan Akibat Hukumnya" Tesis Universitas Diponogoro. 
Sula, Muhammad Syakir, Asuransi Syariah (life and General) Konsep dan Sistem Operasional, Jakarta: Gema Insani, 2004.

Fuady, Munir, Hukum Kontrak dari Sudut Pandang Hukum Bisnis, Bandung: Citra Aditya Bakti, 2001.

Otoritas Jasa Keuangan, "Asuransi Sarana Proteksi dan Investasi,” 19. http:// sikapiuangmu. ojk. go.id/.../ Asuransi.pdf.

Patrik, Purwahid, Dasar-dasar Hukum Perikatan: perikatan yang lahir dari perjanjian dan dari undangundang, Bandung: Mandar Maju, 1994.

R. Subekti, Aneka Perjanjian, Bandung: Alumni, 1977.

R. Subekti, Pokok-pokok Hukum Perdata, Jakarta: Intermasa, 2005.
Fatwa Dewan Syariah Nasional Majelis Ulama Indonesia nomor 51/DSN-MUI/III/2006.

Putusan Mahkamah Agung Nomor: 2831 K/Pdt/1996 tanggal 7 Juli 1999

Putusan Pengadilan Tinggi Agama Makasar Nomor: 59/Pdt.G/2009/PTA.Mks tanggal 15 Juli 2009

Putusan Pengadilan Agama Makasar Nomor 732/ Pdt.G/2008/PA.Mks tanggal 2 Maret 2009

Putusan Mahkamah Agung RI Nomor 16 K/AG/2010 tanggal 30 April 2010

Putusan PA Bekasi Nomor: 1526/Pdt.G/2010/PA.Bks

Putusan PTA Bandung Nomor: 168/Pdt.G/2012/PTA. Bdg 